\title{
A MODEL ABORIGINAL STATE
}

\author{
Michael Roe
}

Throughout the nineteenth century, in both the United Kingdom and its colonies, the petition to Parliament was a major weapon in the armoury of politics. For reasons which no one appears to have explained, this ceased to be so in more recent times. Few petitions appear in twentieth-century Parliamentary Papers throughout Australia, the rarity being even greater at Federal than State level. That makes the petitions that are extant all the more interesting. Perhaps none makes the point better than that submitted to the Federal House of Representatives late in 1927, calling for 'A Model Aboriginal State'. ${ }^{1}$ The petitioners showed that itch of conscience, persistent despite and because of its impotence, which always beset some white Australians when confronting the Aboriginal disaster. Their work synthesized a dialectic between hopes for a better post-war world and such realities as the East Kimberley massacre of mid-1926. The whole story merits a little more attention than it has so far received. ${ }^{2}$

The central text of the petition ran thus:

That Whereas:-

1. It was not only a moral duty, but also a strict injunction included in the Commission issued to those who came to people Australia that the original occupants should be cared for.

2. The Aboriginal races are mostly fast dying out because:

(a) Our well-meant and costly experiments in their interests have not been sufficiently on the right lines.

(b) There have been cases of individual cruelty and oppression which it has been practically impossible for the Governments to deal with.

(c) Owing to domestic preoccupation so many citizens of Australia have overlooked the claims of the native races and not realized what the alienation of their hunting grounds meant to them.

(d) The self-sacrificing efforts of missionaries who have done inestimable work have been necessarily limited.

3. In their wild state the natives for centuries have been nomads and hunters but since white occupation their position has become serious, and with the increased pastoral occupation following the construction of railways their already greatly depleted sources of food supplies will be further diminished.

Michael Roe has taught in the History Department, University of Tasmania, since 1960. A Fellow of the Australian Academy of the Humanities, his most recent book is Nine Australian Progressives /University of Queensland Press, 1984).

The author's thanks are due to the officers of the Bills and Papers Office, Parliament House, Canberra.

1 Votes and Proceedings, House of Representatives 1926-27-28, vol 1:691-4.

2 The matter is noticed, and well set in context, by Biskup 1973:88-89. 
4. The opinion so generally held that the Australian native is the lowest type of humanity in the world is now found to be quite erroneous. On the contrary he does not belong to any negro race and has been proved to possess great mental powers, ability to quickly learn, and can be taught agriculture, engineering, carpentering, \&c., while there are already a number of native Christian clergy.

5. If we regard the native races as our spiritual equals, if we recognize their rights and do not treat them merely as chattels, if we assist them to accommodate their methods to new conditions, if we return to them areas of country on which they may work out their own salvation safeguarded from the envious eyes of encroaching white population, we shall at least have the satisfaction of knowing that even at the eleventh hour we have endeavoured to redeem any neglect, indifference or maladministration in the past and to do substantial justice. And the aboriginal will pay us back. We shall assuredly find that we have races of people who will be of immense help in developing our empty Northern Estate particularly in the more torrid zones. And we shall find that, relieved of so much attention to material affairs, the self-sacrificing spiritual work of missionaries will be greatly accelerated.

Your Petitioners therefore humbly pray that your Honourable House -

1. (a) Will cause to be constituted a model Aboriginal State to be ultimately managed by a native tribunal as far as possible according to their own laws and customs but prohibiting cannibalism and cruel rites. In the meantime such assistance, as may be necessary, to be given, the greatest care to be exercised that only those of the highest ability and the very fullest sympathy should be selected for this work. Provision to be made that ultimately the Government may be conducted by aborigines, and that it would be possible at some future time that the Administrator himself could be a native.

(b) The Constitution to prohibit, under a very severe penalty, any persons, other than aborigines, except Federal Government officials and duly authorized missionaries, teachers and agricultural instructors from entering this State.

(c) The governing tribunal to decide the extent to which control shall be exercised over such natives still in their wild conditions as are within the State.

(d) No native to be detained in the State against his will but upon his leaving any land allotted to him to revert to the Crown.

(e) The State to have representation in the Federal Parliament on the lines (in a modified form at first) of the Maoris in New Zealand.

(f) That every assistance be given to the governing tribunal for the rigorous medical control and treatment of contagious diseases, especially venereal and tubercular.

Among the many full-blooded aboriginals competent to assist in founding the proposed State may be mentioned Rev. Jas Noble and Mr David Unaipon, who is at present engaged in anthropological work at the Adelaide University.

It is noted that no attempt should be made to force any natives into the proposed State, the nucleus of which to be those tribes now occupying the country to be transferred. If these new plans are found to be on the right lines it will be, no doubt, advisable later on to create one or more other Native States.

2. (a) That, with regard to Aborigines who come in contact with white people, the regulations and supervision should be tightened up so as to prevent to a greater extent the blighting influence of immoral Europeans and others. 
(b) That natives who have no regular approved employment or are hangers on to the fringe of civilization should be removed far away from possible contaminating contacts.

(c) That annual returns should be required from all persons who have or had during the past year Aborigines in their employ.

The Bills and Papers Office at Parliament House, Canberra, holds the originals of the petition (bearing 7,113 signatures) and some associated documents, which hint at the background story to the petition. A circular, dated from Adelaide in early November 1926, reported that by then some 1,000 signatures had been gathered, all States being represented, and that a meeting of sympathisers on 2 November had decided to form an 'Aborigines' Protection League' to pursue the good work. The provisional committee then formed had twenty-four members. Included were Herbert Basedow (chairman), long-time enthusiast for Aboriginal culture and protection; the Reverend John Blacket, writer of much popular Methodist history; Professor Darrley Naylor, classicist at the University of Adelaide; W. Ramsay Smith, head of public health in the State and a sympathetic observer of Aboriginal life; and David Unaipon, mentioned in the petition. The proportion of women was sizeable, and Blacket was not the only Protestant cleric. Christian allegiance doubtless was the strongest single force among the activists, and overall the committee had the image of bourgeois philanthropy so pervasive in welfare crusades throughout Australian history. A General Meeting of 26 November confirmed the moves of three weeks before, and the League was formally established, constitution and all. Probably the main effect was to quicken the collection of signatures.

A 'Manifesto' that accompanied the blank forms made its chief points again, with some elaboration. It stressed, for example, that the Aborigines were markedly less caste-conscious than were Indians: an argument which now rings rather odd, but would have made more sense at a time of heated debate as to whether Britain should allow India self-government. The Manifesto asserted that 'the growth of a sense of nationhood' must work upon the Aborigines as a powerful stimulus for good. The petition's reference to these people being 'spiritual equals' with Europeans expanded into the suggestion that their 'religion, laws and customs' had full legitimacy. This created an embarrassment in regard to the churches' work, resulting in the clumsy phrase that 'to invite them to replace their religion by Christianity may safely be left to the self-sacrificing missionaries'. More confidently the Manifesto contrasted the Aboriginal situation with that prevailing in territories held under League of Nations mandate, where Australia had to justify its policies to the world. The current Federal Government, and especially the relevant minister, G.F. Pearce, had shown goodwill, but in stark fact official policies had failed. The most powerful passage of the Manifesto lamented the fate of Aboriginal and half-caste children, who

are taken from their country, their home, their parents, from environments where they should have the opportunity of settling down and marrying and they are placed in strange surroundings with people of alien habits and speech, ostracised from association on equal terms with white children, shut off from the hospitality of white people generally and not permitted to marry, and unable to share in national traditions which are held to be most powerful factors in creating character. Even with the greatest kindness from those in whose charge they are placed, what sense of loneliness, of exile, even of slavery must they not constantly feel. 
The case could scarcely have been put better.

Perusal of the 98 separate petition folios tells the historian a little more. The overwhelming proportion of signatures derived from Adelaide suburbia, Norwood, Gawler, and Henley Beach having very strong representation. Both locations and calligraphy indicate that more ordinary folk were among the signatories than the composition of the committee might have suggested. One of the two petitions from Melbourne embraced the social range from Fitzroy to Toorak within its thirteen signatories; the other from that city derived from Charles Strong's Australian Church. Neither contains names of note, thus contrasting with the Sydney contribution. C.E.W. Bean, George Collingridge, David Stead, Albert Rivett, E.G. Waterhouse, A.B. Walkom: all these Sydneysiders had their fame. Wealthy suburbs of the north shore line were much to the fore among the Sydney addresses. Despite the organisers' claim, there seems to have been little response from the outlying States.

The House of Representatives first heard of the Petition on 13 October 1927. On that day D.S. Jackson (Nationalist; Bass, Tasmania) moved for a joint select committee to consider the plight of the Aborigines and especially the case for 'segregation in large areas in the Northern Territory of its present aboriginal population'. Jackson had recently visited the Northern Territory and the experience seems to have inspired this effort, the most notable event in his competent but humdrum parliamentary career. He referred to the work of the Aborigines' Protection League in favourable way, albeit indicating some reservations as to its scheme. N.J.O. Makin (Labor; Hindmarsh, South Australia) was more emphatic in praising the League's work and echoed Jackson's stress on the need to save the race; he said that only the absence of W.L. Parsons (Nationalist; Angas, South Australia) had delayed presentation of the 'Model State' petition: Next to contribute was C.W.C. Marr, who reported that soon after becoming Minister for Home and Territories in the preceding April he had received a delegation which called for a Royal Commission into the Aboriginal situation. That David Stead was a member of this deputation gave it some tie with the 'Model State' petition. Very likely a common impetus for both efforts was the East Kimberley massacre, echoes of which sounded throughout all these Parliamentary debates. Marr said further that Cabinet had agreed to a submission presented by himself, and that consequently the States had been invited to consider co-operating in such a Commission as had been suggested. The Government's good faith in the matter is open to question: Prime Minister S.M. Bruce became notorious for responding to problems by sending them off for inquiries which often proved long in span but short in effect, while Marr's response to Jackson's motion was 'political' in the narrowest sense. 'If we were to broadcast to the world that nearly 100 years ago the aborigines were treated in a dastardly way - and admittedly they were - we should do injury to our White Australia policy; whereas we wish to convince the world that we are as mindful of our black brethren as of the whites.'

Parsons duly presented the Petition on 20 October, but when the Representatives again debated Aboriginal affairs on the 28th the initiative came from a different quarter. The Labor member for the Northern Territory, H.G. Nelson, then moved for discussion of "the exploitation of native labour in North Australia'. His complaint was against Aborigines being allowed to supply railway sleepers on government contract, at allegedly exploitative rates, while white men went jobless. Marr replied with a vigour he rarely showed. His assertion that Nelson sought only to secure a trade union monopoly seems a fair enough comment. $\mathrm{He}$ took the opportunity to slash at the 'Model State' as well: 'I say that if you want to destroy our aborigines in the North, the best thing to do is to put them into a State of their own; 
they will then annihilate each other'. Nelson's motion was defeated on straight party lines, Parsons and Jackson conforming to the Whip. When Parsons spoke to Jackson's motion (3 November) he upheld the 'Model State' notion, albeit disclaiming any personal responsibility for its origin and insisting that no precipitate action was intended. Basedow and Ramsay Smith were among the authorities he cited in support of the Aborigines'capacity and dignity.

On 6 December Bruce told the House that the Royal Commission proposal had failed, the States having offered but little co-operation. Hence the Government would ask Queensland to lend a senior official to report on Aboriginal matters in Central and Northern Australia. In the weeks ahead Parsons, Jackson, and Makin several times asked questions on this matter, guarding against the whole issue disappearing into some pigeon-hole. Parsons won a promise that the 'Model State' would come within the inquiry.

The outcome of this activity was a report by J.W. Bleakley, Queensland's Chief Protector of Aborigines. C.D. Rowley and others have found a good deal to praise in this document. ${ }^{3}$ One of its more forceful passages scorned the idea of a separate State:

The above scheme evidently assumes that the natives have, or can be expected to develop, qualities that they have never so far displayed. They have no conception of democracy as understood by civilized nations. Their native laws and customs seem to utterly fail to conceive any idea of combination or federation of tribes for mutual government or protection. Each tribe is a separate and distinct group, with its own language, customs, and laws environing its peculiar totem, and has interest in nothing outside of those associations. Any interference with the government of the tribe by an elected tribunal, even if such a body could be created, would be bitterly resented. ${ }^{4}$

Bleakley claimed that his own views had the backing of David Unaipon, despite the petitioners' invoking his name.

That could have been so. The 'Model State' idea sprang from benevolence and a sense of outrage at sufferings imposed on the Aborigines. ${ }^{5}$ It did not promise a line of action viable in either political or anthropological terms. By all these tokens, the passage is one highly indicative of its times.

3 Rowley 1970:259-70; Yarwood and Knowling 1982:252.

4 Bleakley 1929:1188.

5 Roe 1986 indicates support for the idea among theosophists in Sydney and Adelaide.

\section{BIBLIOGRAPHY}

Biskup, P.A. Not slaves, not citizens. Brisbane, 1973.

Bleakley, J.W. 'The Aboriginals and Half-Castes of Central and Northern Australia', Commonwealth Parliamentary Papers, 1929, vol. 2:1159-1226.

Commonwealth Parliamentary Debates, Tenth Parliament, First Session; House of Representatives 13 October 1927:507-18,523-24; 20 October 1927:633; 28 October 1927:809-22; 3 November 1927: 955-58; 23 March 1928:4124.

Roe, Jill. Beyond belief: theosophy in Australia 1870-1939. Sydney, 1986.

Rowley, C.D. The destruction of Aboriginal society. Aboriginal policy and practice, vol.1. Canberra, 1970. Yarwood, A.T. and M.J. Knowling. Race relations in Australia. North Ryde, 1982. 


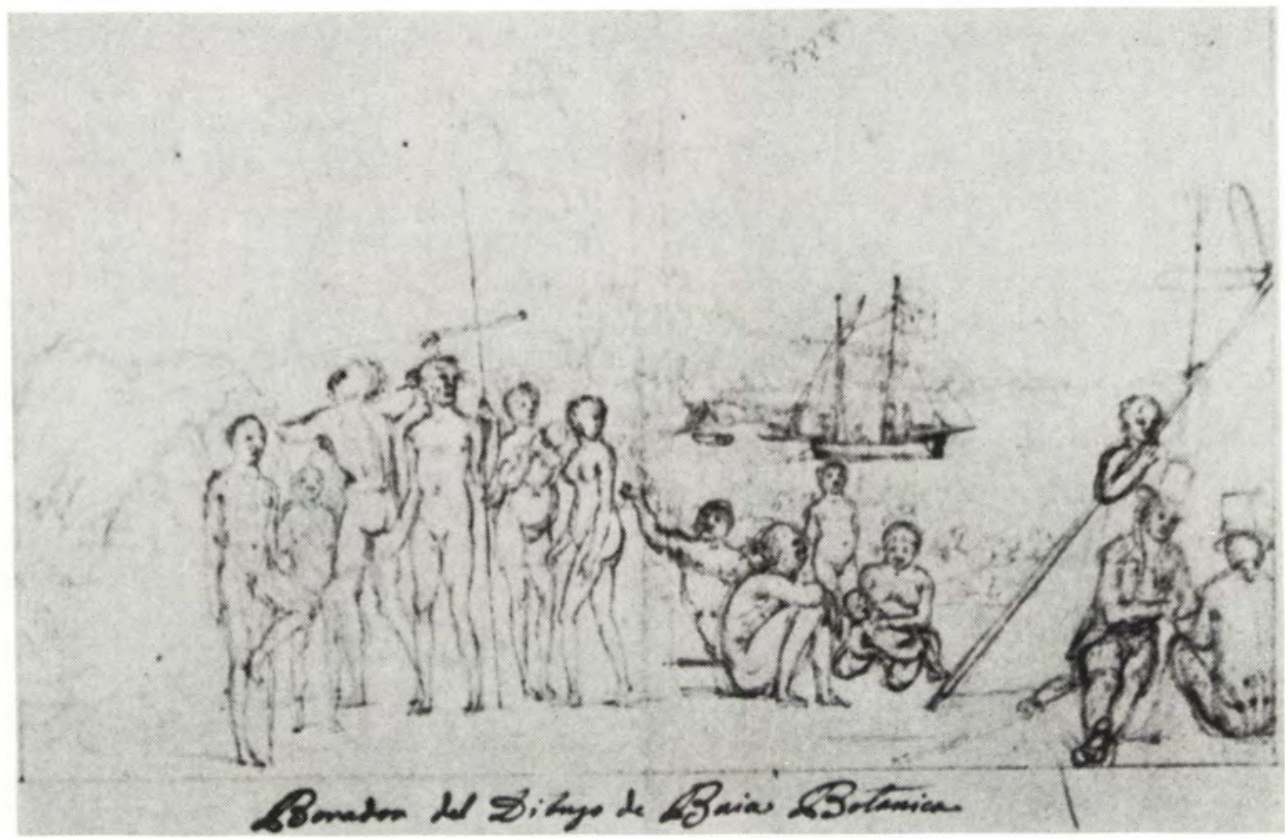

Natives of Botany Bay by Juan Ravenet (State Library of New South Wales)

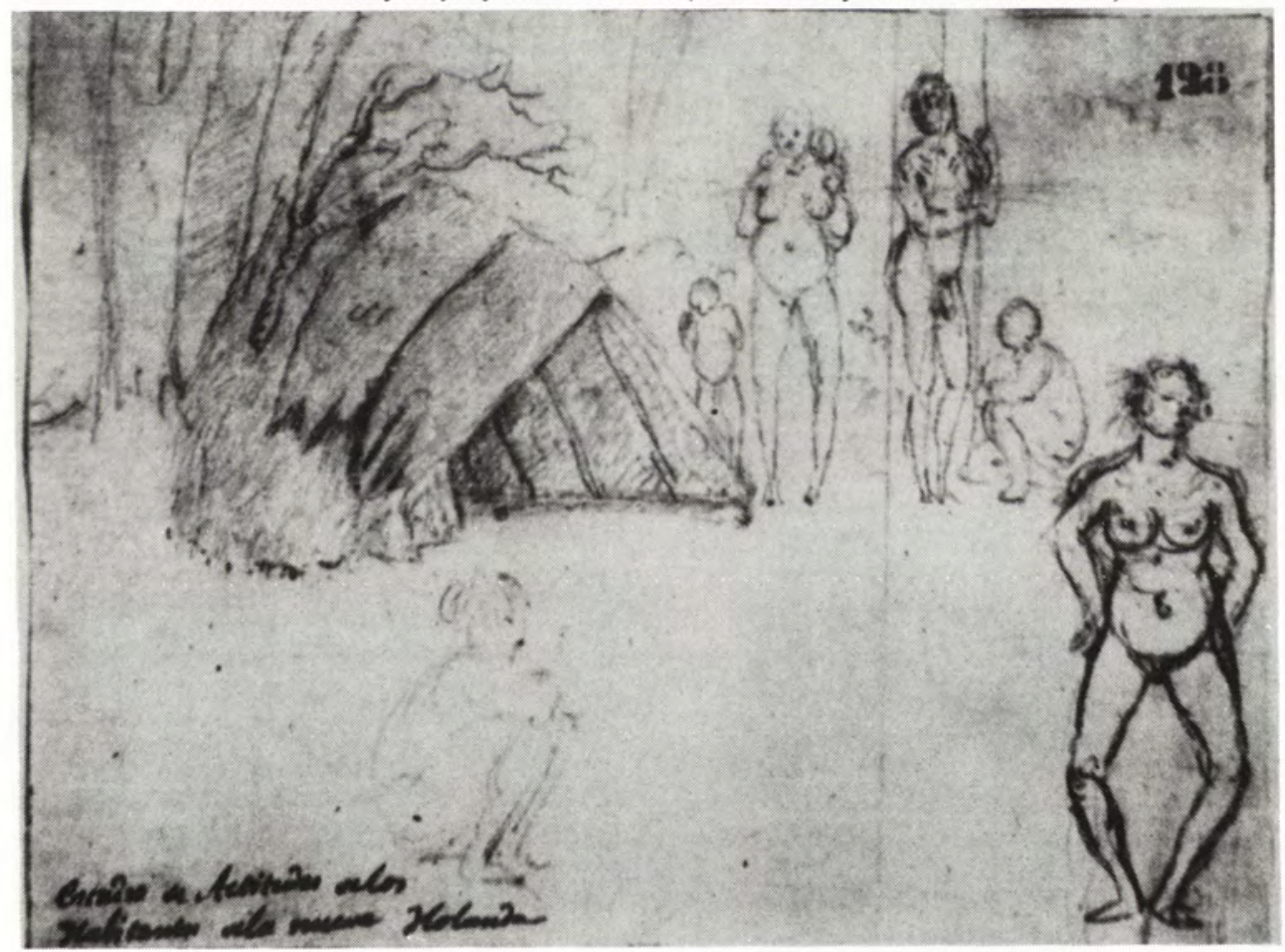

Inhabitants of New Holland by Juan Ravenet (State Library of New South Wales) 
ABORIGINAL HISTORY $1986 \quad 10: 1$

$2 \% 4$

(i.)

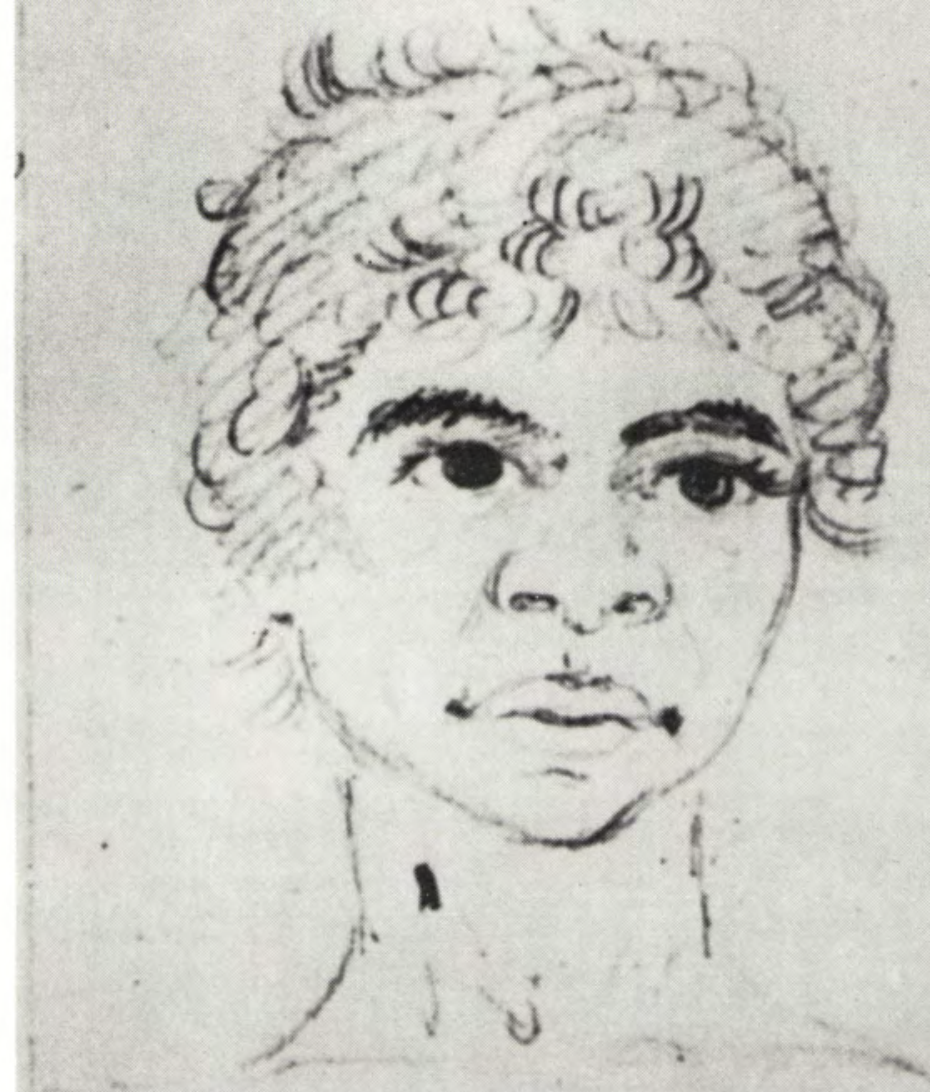

1)

Pareve Mataonde

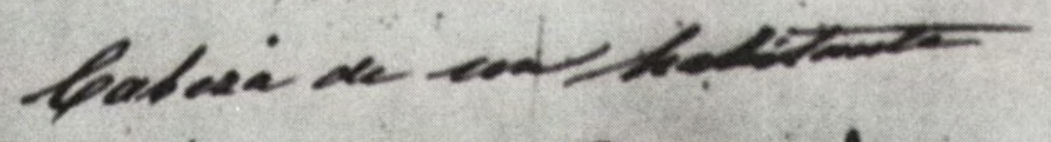

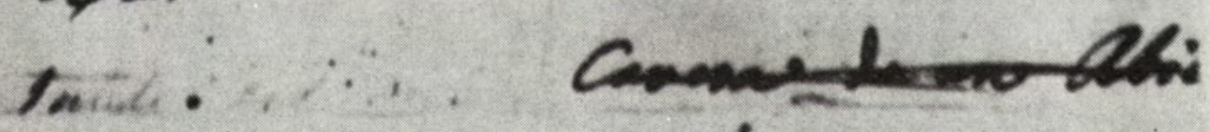

Portrait of an inhabitant of New South Wales by Juan Ravenet (Muse Naval, Madrid)

46 